\title{
Fear, mistrust and misinformation
}

One of the features of the ongoing Ebola virus disease outbreak in the Democratic Republic of the Congo has been massive community distrust, fear and misinformation. As I write, the End of Outbreak Declaration, which was scheduled for Sunday 12 April 2020, was overtaken by events when two new confirmed cases came to light. One of the community responses to this was a demonstration by the youth demanding to know why there were new cases 52 days after the last confirmed case. In this devastating disease, the reasons for not only the emergence of a case after such a length of time, but also the widespread community distrust, which frequently (and often devastatingly) disrupted response activities, were myriad. The main driver, however, was constant insecurity in North Kivu Province in particular, with armed insurgents killing civilians, medical and aid workers, and even one World Health Organization doctor. Misinformation about the disease and misunderstanding of its nature were also rife - not surprisingly, you might think, given the relatively unsophisticated populations affected, and their isolation (although social media is more pervasive than most of us realise).

Throughout time, populations have been scared of infectious diseases - by their very nature they spread, through common and numerous vectors, and they can affect anyone. One of the best-known examples is the bubonic plague outbreaks that devastated Europe regularly between 1347 and 1351 - again, in an unsophisticated population with no knowledge of how the disease was spread and no way of preventing or treating it. An understandable platform for fear, mistrust and misinformation, you might think.

COVID-19 first arose in China towards the end of 2019. At the time of writing there were more than 2 million cases globally, with more than 130000 deaths. The epicentre of the disease is now the USA, with around half a million cases and more than 30000 deaths. Asia was severely affected, but European countries overtook Asia as the disease became global. COVID-19 first appeared in Africa in mid-February and now affects all but two countries on the continent. So far, the spread in Africa has not been as bad as was predicted - but this may still happen.

What has struck me about this particular infectious disease is that the people affected are mainly in high-income countries, with sophisticated education systems. In the UK, which is the only country outside Africa that I know well, even the relatively less well-off have access to sophisticated information systems, good education, and excellent healthcare. The initial cases in Africa were in those who had the means to travel overseas to those countries in Europe where the disease was rife - in other words, mostly the better-off members of the population, with work that required a high level of education. A sophisticated audience, in fact. My 'bubble' on social media is similar - although that has widened as I joined Facebook groups in my local area, some of which are dedicated to COVID-19 information and response, and one of which is administered by a local ENT specialist.

What have I found, both in my own 'bubble' and slightly outside it? Fear, mistrust and misinformation. While working with my WHO colleagues on the current Ebola outbreak, we often discussed the community issues that made response difficult and often dangerous for those on the ground. We all agreed that it was understandable in the face of the particular situation of the affected populations. It has been very interesting to watch how similar issues have pervaded the COVID-19 discourse. Fear is understandable - particularly with such a new and unknown entity. But the levels of mistrust that I have seen have startled me. I have spent lots of time persuading friends, with whom I normally have a lot in common, that 'the authorities' are not hiding facts from us (at least I really do not think they are in South Africa). Thankfully, the recent SABC broadcast with our Minister of Health and Prof. Karim seems to have helped enormously, showing the power, and importance, of transparency. And then there is the misinformation - some relatively unimportant in terms of impact on prevention measures, but some (and I must say none among my actual friends) downright astonishing, as the conspiracy theorists all come out from under their tinfoil hats.

Our world has changed, and is unlikely to ever return completely to where it was. It is rather like living in the middle of a science fiction novel at the moment. But it would seem that fear, mistrust and misunderstanding are universal, and the supposed sophistication of our world is no barrier. Those of us who are involved in any way with the response to this pandemic need to realise this, and work accordingly.

\section{Bridget Farham \\ Editor \\ ugqirha@iafrica.com}

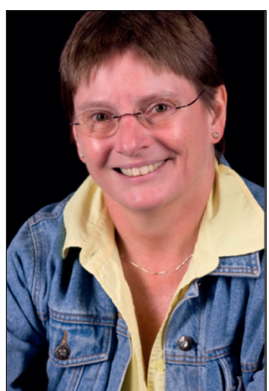

S Afr Med J 2020;110(5):334. https://doi.org/10.7196/SAMJ.2020.v110i5.14817 